\title{
Capital Market Linkage to Economic Growth in Nepal
}

\author{
Jhabindra Pokharel
}

\section{ABSTRACT}

This article examines the causal relationship between capital market development and economic growth in Nepal using annual time series data from 1994-2019. Total market capitalization is used as a proxy of secondary market development and the total public issue of securities in a particular year is taken as an indicator of primary market development. Using the Johansen cointegration test and vector error correction method (VECM) in regression analysis, the study reveals that capital markets in Nepal are supporting economic growth through efficient fundraising, efficient allocation of resources, fair price determination and liquidity. The findings from this study conclude that there is a unidirectional causality running from capital market development to economic growth in both the long-run and short-run. However, this study found no support for causality running from economic growth to the capital market. Therefore, the findings from this study recommend policies that increase the reach of the capital market to small and medium enterprises (SMEs) and individual investors.

Keywords: capital market, market capitalization, primary market, economic growth, Nepal

\section{Introduction}

Within the past two decades, there was a significant interest among researchers regarding the causal relationship between financial development and economic growth. The academic literature on financial sector development and economic growth can be traced back to 1911 when Joseph A. Schumpeter, in his book, The Theory of Economic Development, argued that a well-structured financial system promotes economic growth through encouragement of innovation in business and efficient allocation of resources in the areas where it is needed the most. However, this topic gained importance among economists in the 1990s. This may be the effect of the globalization of business, the advancement of technologies in the financial market and global integration of financial markets. A well-structured, efficient, systematized and sustainable financial system is a prerequisite for real sector growth (Mishkin \&
Eakins, 2018). The development of the capital market reflects the economic growth of a country because the need for investment in fixed assets in the expansionary economy is financed by raising funds from capital markets (Levine \& Zervos, 1998). Another important function of the capital market is that it offers risk management services that encourage the entrepreneurs to commercialize their innovative ideas, which ultimately results in output growth. Similarly, the capital market offers liquidity in the economy that also aids the efficient allocation of resources in real sectors. The competitive pricing of securities and a large range of financial instruments allow investors to better allocate their funds according to their respective risk and return appetites, thereby, supporting economic growth (Madura, 2015).

Access to finance by small and medium enterprises (SMEs) is a common problem, especially in a developing economy like Nepal. 
The main reasons for the credit constraints of SMEs are the cost and difficulty of evaluating creditworthiness (Wendel \& Harvey, 2006). However, SMEs have a major contribution to economic growth in both developing and developed countries. The development of the capital market eases the credit constraints by making available the financial resources required by SMEs and large corporations. GDP growth of Nepal is low as compared to other south Asian countries, and there is a high trade deficit (Nepal Rastra Bank, 2018). The development of the capital market can help to improve the situation by supporting the implementation of the most innovative entrepreneurial ideas that are necessary for output growth (Ibrahim \& Alagidede, 2017). A well-developed financial market not only supports the innovative ideas to be commercialized, but it also reduces the effect of macroeconomic volatility like higher inflation and volatile interest rates (Aghion et al., 2014).

The development of the financial market supports economic growth more for developing countries than developed countries (Arcand et al., 2015). The studies on other South Asian countries like Pakistan and Bangladesh have also found the capital market development contributing significantly to economic growth (Palamalai \& Prakasam, 2015; Sharif \& Afshan, 2016). Therefore, this study, using annual time series data published by the Ministry of Finance and applying the vector error correction method of analysis, investigates whether the capital market development in Nepal is contributing significantly to economic growth, like in other South Asian countries, through easing credit required by the SMEs and other corporations, and ensuring the efficient allocation of financial resources to the sectors of the economy that need it the most.

\section{Literature Review}

Theoretical literature regarding financial development and economic growth was not much cited before the 1990s even though some economists, such as Schumpeter (1911), emphasized the importance of financial development on economic growth. Some of the studies have findings that support to the supplyleading hypothesis meaning that the capital market development leads to economic growth
(Nguyen, 2019; Omri, et al., 2015). On the other hand, studies by Ho and Odhiambo (2013) and Helhel (2018) found support to demand-following hypothesis meaning that economic growth leads to capital market development. However, Cecchetti and Kharroubi (2015) and Arcand et al. (2015) found a $U$ shaped finance-growth relationship indicating that a certain level of economic growth leads to economic growth which then leads financial sector development.

A cross-country study by Durusu-Ciftci et al. (2017) revealed a positive effect of the capital market on economic growth in the long-run. In Pakistan, stock market development and economic growth are strongly related, in as much as economic growth supports capital market development and capital market development supports economic growth in the long-run. Thus, the development of one ensures the development of the other. However, the short-run the stock market development leads to the economic growth (Nazir et al. 2010). In ASEAN countries, the stock market and economic growth influence each other (Azam et al., 2016; Pradhan et al., 2014). In South Africa, the relation is onedirectional, running from capital market development to economic growth (Nyasha \& Odhiambo, 2015). On the other hand, Odhiambo (2009a) concludes that the causality between economic growth and capital market development is sensitive to the proxy used. However, Pan and Mishra (2017) found a very weak causality between capital market and economic growth in Central Europe. Therefore, the causality between the capital market and economic growth varies with the level of development of the capital market. Looking at the primary market development, Andriansyah and Messinis (2014) found no effect of the primary market on economic growth but did determine its benefit to the development of the secondary market.

The majority of the studies in the financegrowth nexus are cross-country studies that ignore specific characteristics of individual counters such as industrial structure, level of development of the financial market, government control in the financial market and degree of effective governance (Durusu-Ciftci et al., 2017; Omri et al., 2015) . On the other hand, the role of the primary market has been ignored in almost all 


\begin{tabular}{lcccccccc}
\hline & LGDP & LMCAP & LPIS & LFXCAP & LCPI & LINV & LREM & LTO \\
\hline Mean & 9.960 & 14.132 & 7.964 & 22.798 & 1.886 & 12.379 & 11.309 & 12.586 \\
Median & 9.901 & 14.110 & 7.851 & 21.540 & 2.084 & 12.163 & 11.502 & 12.404 \\
Maximum & 10.410 & 16.755 & 10.884 & 36.930 & 2.535 & 14.584 & 13.687 & 14.231 \\
Minimum & 9.636 & 11.720 & 5.538 & 10.200 & 0.884 & 10.706 & 8.152 & 11.169 \\
Std. Dev. & 0.238 & 1.783 & 1.787 & 5.362 & 0.447 & 1.152 & 1.835 & 0.904 \\
\hline
\end{tabular}

Table 1. Summary of Statistic Variables.

Note: $\mathrm{N}=26$. This table presents the descriptive statistics of the variables used in the analysis. Letter $\mathrm{L}$ in all variables denote log operator. GDP $=$ per capita GDP, MCAP $=$ total market capitalization, $\mathrm{PIS}=$ total amount of public issue of securities, $\mathrm{CPI}=$ consumer price index expressed in annual percentage change, INV = total investment in the economy, FXCAP = total amount of fixed capital formation, REM = net amount of remittance, and TO = trade openness expressed as a sum of import and export.

\section{Source: Ministry of Finance, Nepal and World Bank Database}

studies. The contribution of this study to the existing literature is that it focuses on a single country, Nepal, unlike other cross-country studies. Additinoally, it includes both secondary and primary market development, which is not considered by other studies.

\section{Variables and Data}

\section{Variable Definitions}

Real GPD per capita is taken as the measurement of economic growth, specificially, output growth including the contribution of labor, physical capital and human capital. GDP per capita is the most frequently used variable in literature to measure the total output growth with population growth (Bayar et al., 2014Estrada et al., 2010;). Since the size of the secondary market is reflected by total market capitalization (Arestis et al., 2001), it is taken as a proxy of secondary market development. However, the secondary market cannot represent the whole capital market in Nepal because many of the private companies have not listed their shares and bonds in the secondary market. Therefore, to include the role of the primary market separately, the public issue of securities by private corporations is taken as a proxy of primary market development.

Economic growth may be affected by many other factors besides stock market development. To check whether the causality between capital market and economic growth remains the same, even if the impact of other variables are also considered, macroeconomic variables such as remittance, fixed capital formation, total investments, consumer price index and trade openness are also used as control variables in various regression equations.

\section{Data}

The organized secondary market in Nepal was started in 1994 after the establishment of the Nepal Stock Exchange (NEPSE) in the same year. Therefore, 26 years of annual time series data for all variables was taken from 1994 to 2019. All data was taken at its real-time value. However, GDP per capita was taken as a 2010 constant price. All data was log transferred to normalize the trend in the data series. Data for all variables except for GDP per capita were taken from the Ministry of Finance, Nepal. However, data for real GDP per capita was taken from the World Bank database. Table 1 presents the summary of statistics of dependent, independent and control variables used in the study.

\section{Test of Stationary}

In time-series data, there may exist a time trend. To check for the presence of trend or unit root, the Augmented Dickey-Fuller (ADF) and Phillips- 


\begin{tabular}{|c|c|c|c|c|c|}
\hline \multirow{2}{*}{ Variables } & \multicolumn{2}{|c|}{$\mathrm{ADF}$} & \multicolumn{2}{|c|}{ PP } & \multirow{2}{*}{$\begin{array}{l}\text { Order of } \\
\text { integration }\end{array}$} \\
\hline & Level & $I^{s t}$ Diff & Level & ${ }^{I^{s t}}$ Diff & \\
\hline LGDP & 2.5626 & $-4.1317^{* *}$ & 9.1569 & $-4.1067 * *$ & $I(1)$ \\
\hline LMCAP & -0.3173 & $-3.4609 * *$ & -0.4014 & $-3.4866^{* *}$ & $I(1)$ \\
\hline LPIS & -0.5231 & $-6.6276^{* *}$ & -0.3144 & $-6.6276^{* *}$ & $I(1)$ \\
\hline LREMI & -1.3267 & $-5.6044 * *$ & -1.4293 & $-5.5889^{* *}$ & $I(1)$ \\
\hline LTO & 1.6156 & $-5.3347^{* *}$ & 2.6701 & $-5.1340^{* *}$ & $I(1)$ \\
\hline LINV & 1.1687 & $-4.3540 * *$ & 3.7900 & $-4.3201^{* *}$ & $I(1)$ \\
\hline LFXCAP & 0.9102 & $-6.4302^{* *}$ & 0.4234 & $-6.3947^{* *}$ & $I(1)$ \\
\hline LCPI & -2.3762 & $-5.9552 * *$ & -2.3562 & $-5.9341^{* *}$ & $I(1)$ \\
\hline
\end{tabular}

Table 2. Unit Root Test.

Note: This table presents the results of the test of unit root in data using the Augmented Dickey-Fuller (ADF) test and Phillips-Perron (PP) test at their level and first difference. $/(1)$ denotes that the variable is stationary at first difference.

** denotes $p<0.05$.

Perron (PP) tests were applied, using the equation (1) in the process.

$\Delta Y_{t}=\alpha+\gamma Y_{t-1}+\lambda t+\beta_{i} \Delta Y_{t-j}+\varepsilon_{t} \ldots \ldots(1)$

where $t$ is the time index, $\alpha$ is an intercept, $\lambda$ is the coefficient on a time trend, $y$ is the coefficient presenting process root, $p$ is the lag order of the first-differences autoregressive process, and $\varepsilon t$ is an independent identically distributed residual term. Table 2 shows that all the variables are not stationary at level in either the ADF or the PP tests. However, in the first difference, all become stationary as $p<0.05$.

\section{Econometric Methodology}

This study follows the following basic models:

$\mathrm{GDP}_{\mathrm{t}}=\alpha+\beta(\mathrm{CD})_{\mathrm{t}}+\lambda(\text { Control })_{\mathrm{t}}+\varepsilon_{\mathrm{t}}, \ldots \ldots(2)$
$\mathrm{CD}_{\mathrm{t}}=\mathrm{\gamma}+\delta(\mathrm{GDP})_{\mathrm{t}}+\varphi(\text { Control })_{\mathrm{t}}+\mathrm{U}_{\mathrm{t}}, \ldots \ldots$ (3)

where GPD represents per capita GDP, CD represents capital market development indicators, and control consists of macroeconomic variables used as control variables. The two financial development indicators were total market capitalization and total public issue of securities. Control variables included net remittance, fixed capital formation, trade openness, total investment and change in consumer price index. Equation (2) was used to check the causality of capital market development on economic growth and Equation (3) for reverse causality.

\section{Johansen Cointegration Test}

The variables in this study were not stationary at level, which indicates that they may be cointegrated. The presence of cointegration was checked by using Trace statistics developed by Johansen (1991).

$$
\lambda_{\text {trace }}(r)=-T \ln (1-\hat{\lambda} \mathrm{i}) \ldots \ldots(4)
$$

where $T=$ number of observations and $\hat{\lambda} i=$ the estimated value of the characteristic roots. If the series were cointegrated, a vector error correction model (VECM) was used. Since all variables in the present study were $I(1)$, the 


\begin{tabular}{lcccc}
\hline & \multicolumn{3}{c}{ Hypothesized No. of CE(s) } & Identified \\
\cline { 2 - 4 } Models and variables & None & At most 1 & At most 2 & No. of CE(s) \\
& $(\mathrm{r}=0)$ & $(\mathrm{r} \leq 1)$ & $(\mathrm{r} \leq 2)$ & \\
\cline { 1 - 4 } & $24.085^{*}$ & 1.9554 & & 1 \\
Model 1: LGDP, LMCAP & $46.8076^{*}$ & 9.8633 & 0.0121 & 1 \\
Model 2: LGDP, LMCAP, LREMI & $44.2747^{*}$ & 13.3573 & 0.4801 & 1 \\
Model 3: LGDP, LMCAP, LFXCAP & $48.388^{*}$ & 23.6685 & 7.7889 & 1 \\
Model 4: LGDP, LMCAP, LREMI, LTO & $42.2633^{*}$ & 11.1194 & 2.4628 & 1 \\
Model 5: LGDP, LMCAP, LREMI, LCPI, & $168.80^{*}$ & $93.70^{*}$ & $48.33^{*}$ & 3 \\
Model 6: LGDP, LMCAP, LREMI, LCPI, LTO & & & & \\
\hline
\end{tabular}

Table 3. Cointegration between Market Capitalization and Per Capita GDP.

Note: This table presents the results from the test of cointegration using Trace statistics. LGDP is a dependent variable and LMCAP is a secondary market development indicator. $\mathrm{CE}=$ cointegrating equations.

*denotes $p<0.05$.

VECM method was applied in regression analysis.

\section{Vector Error Correction Method (VECM)}

Engle and Granger (1987) show that if $\mathrm{Y}_{1 t}$ and $Y_{2 t}$ are cointegrated with the same order, then a VECM can be used to analyze the relationship among these variables.

$$
\begin{aligned}
& \Delta \mathrm{Y}_{\mathrm{t}}=\beta_{0}+\beta_{\mathrm{i}} \Delta \mathrm{Y}_{\mathrm{t}-\mathrm{i}}+\theta_{\mathrm{i}} \Delta \mathrm{X}_{\mathrm{t}-\mathrm{i}}+\delta_{\mathrm{i}} \Delta \mathrm{A}_{\mathrm{t}-\mathrm{i}}+\varphi \mathrm{Z}_{\mathrm{t}-} \\
& 1+\mu_{\mathrm{t}} \ldots \ldots \text { (6) } \\
& \text { where } \mathrm{Y} \text { represents the dependent }
\end{aligned}
$$
variable, $X$ represents the independent variables, $A$ represents control variables and $Z$ is the error correction term (ECT), which is the OLS residuals from the following long-run cointegrating regression:

$$
E C T_{t-1}=Y_{t-1}-\beta_{0}-\beta_{i} X_{t-1}-\beta_{i} A_{t-1} \ldots \ldots(7)
$$

\section{Results}

\section{Causality between Secondary Market and} Economic Growth
The causal relationship between market capitalization and per capita GDP is analyzed in seven different model specifications with altering control variables. Table 3 presents the different model specifications and their order of cointegration. The results confirm that variables in the model were cointegrated and at least one cointegrating equation could be formed from each model. Thus, VECM was applied in regression.

Panel A of Table 4 reports the coefficients of long-run causality from market capitalization to per capita GDP. Market capitalization is the variable of main interest in 


\begin{tabular}{|c|c|c|c|c|c|c|}
\hline Model & 1 & 2 & 3 & 4 & 5 & 6 \\
\hline \multirow[t]{2}{*}{ LMCAP } & $0.175^{* *}$ & $0.313 * *$ & $0.166^{* * *}$ & $0.178 * *$ & $0.447 * *$ & $0.05 * *$ \\
\hline & $(15.14)$ & $(8.03)$ & (14.12) & $(4.31)$ & $(8.79)$ & $(10.46)$ \\
\hline \multirow[t]{2}{*}{ LREMI } & & $-0.111^{* *}$ & & -0.034 & $-0.24 * *$ & $-0.03 * *$ \\
\hline & & $(-3.09)$ & & $(-1.21)$ & $(-5.16)$ & $(-6.65)$ \\
\hline \multirow[t]{2}{*}{ LFXCAP } & & & $0.01 * *$ & & & \\
\hline & & & $(2.40)$ & & & \\
\hline \multirow[t]{2}{*}{ LTO } & & & & $0.134 *$ & & $0.25 * *$ \\
\hline & & & & $(1.67)$ & & $(31.18)$ \\
\hline \multirow[t]{2}{*}{ LCPI } & & & & & $-0.19^{* *}$ & $-0.03 * *$ \\
\hline & & & & & $(-3.15)$ & $(-6.22)$ \\
\hline $\mathrm{C}$ & 7.47 & 6.79 & 7.38 & 6.14 & 6.72 & 6.54 \\
\hline \multicolumn{7}{|c|}{ Panel B: Model statistics } \\
\hline $\operatorname{Adj} R^{2}$ & 0.568 & 0.703 & 0.711 & 0.632 & 0.693 & 0.563 \\
\hline DW & 2.17 & 1.87 & 2.51 & 1.67 & 2.14 & 1.97 \\
\hline F-stat & $6.796^{* *}$ & $8.436^{* *}$ & $8.72^{* *}$ & $5.19 * *$ & $6.53^{* *}$ & $3.58^{* *}$ \\
\hline \multicolumn{7}{|c|}{ Panel C: Error correction term (t-ratios in parentheses) } \\
\hline \multirow[t]{2}{*}{ ECT } & $-0.148 * *$ & $-0.093 * *$ & $-0.161^{* *}$ & $-0.10 * *$ & $-0.091 * *$ & $-0.64 * *$ \\
\hline & $(-4.56)$ & $(-4.96)$ & $(-5.41)$ & $(-3.81)$ & $(-4.82)$ & $(-3.40)$ \\
\hline
\end{tabular}

Table 4. Market Capitalization Regression on Per Capita GDP.

Note: $\mathrm{ECT}=$ Error Correction Term. DW $=$ Durbin-Watson statistics

${ }^{*} p<0.05$ and ${ }^{* *} p<0.01$.

this analysis. Model 1 is a bivariate model, which does not include controls. All other models include certain control variables. All the coefficients of LMCAP were positive and statistically significant at $1 \%$ level. The coefficient in model 1 is 0.175 , which indicated that a $1 \%$ increase in market capitalization leads to $0.175 \%$ increase in per capita GDP. The same method of interpretation is applied to all other coefficients too. Although the elasticity of coefficients of LMCAP has changed with the inclusion of controls in the model, still they retain their significance. This shows that market capitalization significantly contributes to the economic growth of Nepal in the long-run. This also implies that the price discovery function and liquidity functions offered by the secondary markets have an important role in effective 
resource allocation that results in output growth. Similarly, fixed capital formation and trade openness contribute positively to output growth. However, the consumer price index has a negative impact on economic growth indicating that macroeconomic volatility hinders economic growth.
Panel B of Table 4 presents the model statistics. All models are significant at the 5\% level. Panel $\mathrm{C}$ shows the coefficients of error corrections with their respective t-ratios in parentheses. It is considered as good in terms of model fit if this coefficient lies between 0 to -1 ; however, if it lies between 0 to -2 , independent variables can explain the dependent variable to some extent (Samargandi et al., 2015). All

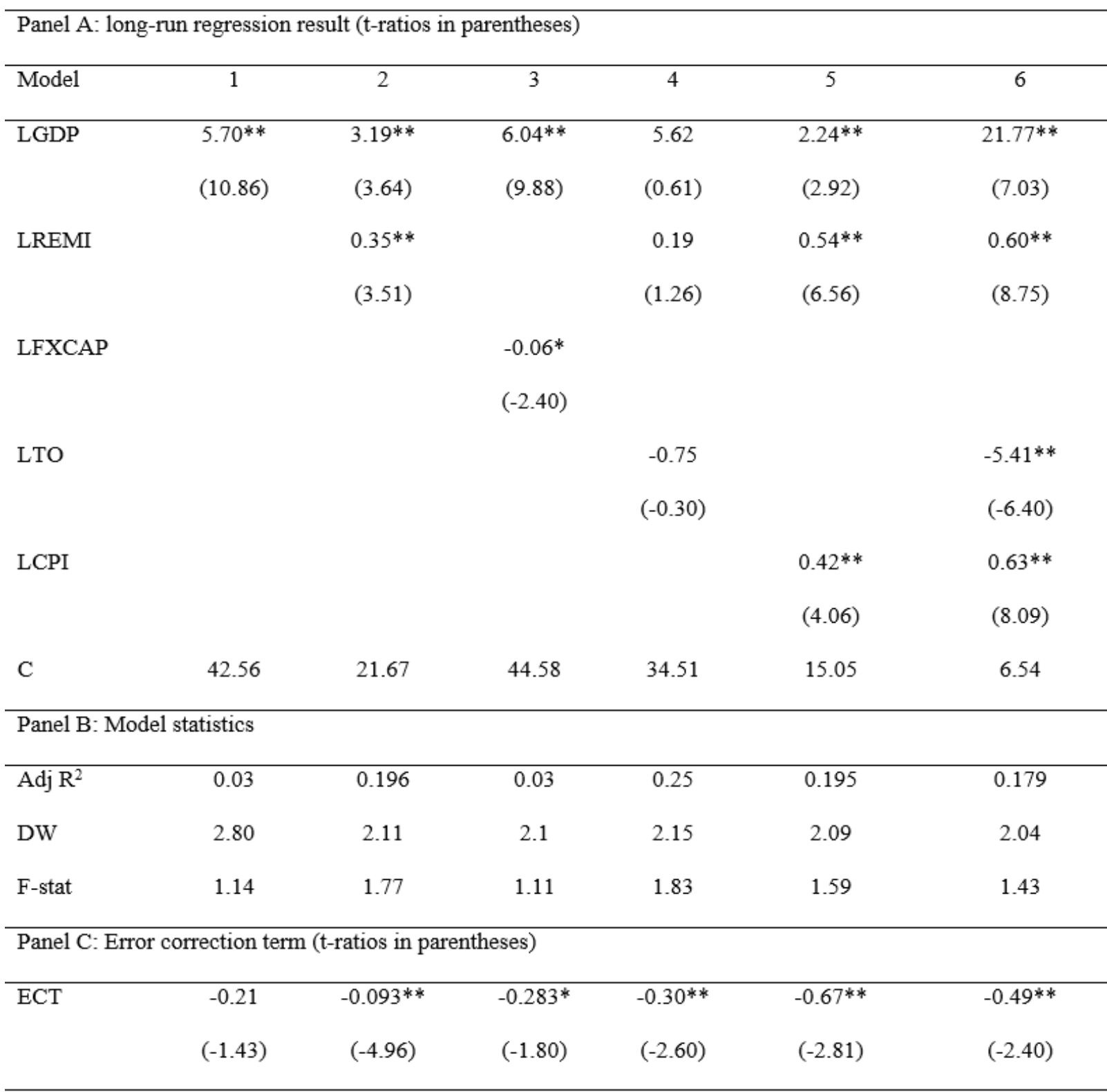

Table 5. Per Capita GDP Regression on Market Capitalization Note: $\mathrm{ECT}=$ Error Correction Term. DW $=$ Durbin-Watson statistics

${ }^{*} p<0.05$ and ${ }^{* *} p<0.01$ 


\begin{tabular}{|c|c|c|c|c|c|c|c|c|c|c|c|c|}
\hline & \multicolumn{2}{|c|}{ Model 1} & \multicolumn{2}{|c|}{ Model 2} & \multicolumn{2}{|c|}{ Model 3} & \multicolumn{2}{|c|}{ Model 4} & \multicolumn{2}{|c|}{ Model 5} & \multicolumn{2}{|c|}{ Model 6} \\
\hline & LGDP & LMCAP & LGDP & LMCAP & LGDP & LMCAP & LGDP & LMCAP & LGDP & LMCAP & LGDP & LMCAP \\
\hline \multirow[t]{3}{*}{ GDP } & & 0.95 & & 3.1 & & 1.15 & & 4.13 & & 2.06 & & 1.21 \\
\hline & & $(.62)$ & & $(.21)$ & & $(.56)$ & & $(.13)$ & & $(36)$ & & $(.54)$ \\
\hline & \multicolumn{2}{|l|}{20.36} & \multicolumn{2}{|l|}{23.69} & \multicolumn{2}{|l|}{31.56} & \multicolumn{2}{|l|}{13.69} & \multicolumn{2}{|l|}{21.26} & \multicolumn{2}{|l|}{10.24} \\
\hline LMCAP & \multicolumn{2}{|l|}{$(00)$} & \multicolumn{2}{|l|}{$(00)$} & \multicolumn{2}{|l|}{$(00)$} & \multicolumn{2}{|l|}{$(\infty)$} & \multicolumn{2}{|l|}{$(. \infty)$} & \multicolumn{2}{|l|}{ (.01) } \\
\hline \multicolumn{13}{|c|}{ Panel 2: Residual diagnostics } \\
\hline Test & $x^{2}$ & $p$ & $x^{2}$ & $p$ & $x^{2}$ & $p$ & $\chi^{2}$ & $p$ & $x^{2}$ & $p$ & $x^{2}$ & $p$ \\
\hline Nom & 1.06 & 0.59 & 0.35 & 0.84 & 157 & 0.46 & 131 & 052 & 2.41 & 030 & 0. 10 & 0.95 \\
\hline Auto. & 2.02 & 0.37 & 192 & 0.38 & 5.08 & 0.08 & 1.06 & 0.59 & 4.78 & 0.09 & 1.57 & 0.45 \\
\hline Hetero & 037 & 0.83 & 391 & 0.10 & 212 & 034 & 5.52 & 0.14 & 3.8 & 0.15 & 5.86 & 0.12 \\
\hline
\end{tabular}

Table 6. Short-Run Impact of Market Capitalization on Per Capita GDP.

Note: This table presents the short-run causality between market capitalization and per capita GDP. Panel

A includes the chi-square statistics form the Wald test and their respective $p$-values in parenthesis.

Coefficients are presented as the impact of column variables on row variables. Panel B presents the residual diagnostics: normality (Jarque-Bera statistics), autocorrelation (LM test), and heteroskedasticity

(ARCH effect).

coefficients in our analysis satisfy these criteria. The coefficient of the error correction term shows the speed of adjustment. The error correction term of model 1 is -0.148 , meaning that any deviation in per capita GDP from long-run equilibrium is corrected at a speed of $14.8 \%$ by market capitalization each year. Similar interpretations can be made for other ECT coefficients.

Out of six model specifications, the coefficient of LGDP was significant in five models. Similarly, five out of six coefficients of error correction terms were also significant at a $5 \%$ level. However, none of the model specifications were significant at $5 \%$ and the adjusted $R 2$ values of all models were very small. Therefore, there is no clear evidence to show that economic growth causes capital market development in the longrun.

The short-run causality of market capitalization and economic growth is presented in Table 6. Short-run regression is run by including lag values of differenced variables included in the models. Appropriate lag length is selected by using the Akaike Information Criterion. The combined effect of all lag values of market capitalization on GDP and GDP on market capitalization is examined by using the Wald test. The values in Table 6 should be interpreted as the impact of the column variable on row variables. All coefficients of the short-run influence of LMCAP on LGDP were significant at $5 \%$. However, none of the coefficients of the short-run influence of GDP on MCAP was significant at the $5 \%$ level. This indicates that there is short-run causality running from the capital market to economic growth but not from economic growth to the capital market. The residual diagnostics presented in Panel $B$ confirms that all models are free from normality, autocorrelations and heteroskedasticity problems.

Panel A includes the chi-square statistics form the Wald test and their respective $p$-values in parenthesis. Coefficients are presented as the impact of column variables on row variables. Panel B presents the residual diagnostics: normality (Jarque-Bera statistics), autocorrelation (LM test), and heteroskedasticity (ARCH effect).

\section{Causality between Primary Market and Economic Growth}

Five different models, taking the total public issue as an indicator of primary market development 


\begin{tabular}{|c|c|c|c|c|c|}
\hline \multicolumn{6}{|c|}{ Panel A: Long-run regression coefficients (t-ratios in parentheses) } \\
\hline Model & 7 & 8 & 9 & 10 & 11 \\
\hline \multirow[t]{2}{*}{ LPIS } & $0.31^{* *}$ & $0.028^{* *}$ & $0.63^{* *}$ & $0.87^{* *}$ & $0.044^{* *}$ \\
\hline & $(5.34)$ & $(2.10)$ & $(6.14)$ & $(5.17)$ & $(2.64)$ \\
\hline \multirow[t]{2}{*}{ LREMI } & & & & $-0.38^{* *}$ & \\
\hline & & & & $(-2.78)$ & \\
\hline \multirow[t]{2}{*}{ LFXCAP } & & & 0.02 & & 0.001 \\
\hline & & & $(0.73)$ & & $(0.09)$ \\
\hline \multirow[t]{2}{*}{ LINV } & & $0.205^{* *}$ & & & \\
\hline & & $(10.34)$ & & & \\
\hline \multirow[t]{2}{*}{ LCPI } & & & & & -0.01 \\
\hline & & & & & $(-0.26)$ \\
\hline $\mathrm{C}$ & 7.47 & 7.20 & 4.30 & 7.39 & 9.63 \\
\hline \multicolumn{6}{|c|}{ Panel B: Model statistics } \\
\hline Adj $R^{2}$ & 0.306 & 0.711 & 0.469 & 0.682 & 0.309 \\
\hline DW & 2.24 & 2.28 & 1.65 & 1.86 & 1.97 \\
\hline F-stat & $3.14 * *$ & $6.187 * *$ & $2.86^{*}$ & $5.50^{* *}$ & 2.09 \\
\hline \multicolumn{6}{|c|}{ Panel C: Error correction terms (t-ratios in parentheses) } \\
\hline \multirow[t]{2}{*}{ ECT } & $-0.046^{* *}$ & $-0.67^{* *}$ & $-0.03^{* *}$ & $-0.04^{* *}$ & $0.11^{* *}$ \\
\hline & $(-3.14)$ & $(-6.78)$ & $(-3.98)$ & $(-4.91)$ & $(2.84)$ \\
\hline
\end{tabular}

Table 8. Public Issue Regression on LGDP. ${ }^{*}$ denotes $p<0.05,{ }^{* *}$ indicates $p<0.01$

and their test of cointegration, are presented in Table 7. In all of the models, at least one cointegrating equation can be formed as indicated by trace statistics. 


\begin{tabular}{|c|c|c|c|c|c|}
\hline Model & 7 & 8 & 9 & 10 & 11 \\
\hline \multirow[t]{2}{*}{ LGDP } & $3.22 * *$ & $36.07 * *$ & 1.57 & 1.15 & $22.72 * *$ \\
\hline & $(2.30)$ & $(3.09)$ & $(1.04)$ & $(0.96)$ & $(7.30)$ \\
\hline \multirow[t]{2}{*}{ LREMI } & & & & $0.44 * *$ & \\
\hline & & & & $(3.13)$ & \\
\hline \multirow[t]{2}{*}{ LFXCAP } & & & -0.03 & & -0.01 \\
\hline & & & $(-0.66)$ & & $(0.09)$ \\
\hline \multirow[t]{2}{*}{ LINV } & & $-7.39 * *$ & & & \\
\hline & & $(2.90)$ & & & \\
\hline \multirow[t]{2}{*}{ LCPI } & & & & & 0.30 \\
\hline & & & & & $(0.25)$ \\
\hline $\mathrm{C}$ & 24 & 259.71 & 6.73 & 8.53 & 218.75 \\
\hline \multicolumn{6}{|c|}{ Panel B: Model statistics } \\
\hline Adj $R^{2}$ & -0.03 & -0.04 & -0.25 & -0.16 & -0.07 \\
\hline DW & 1.85 & 1.88 & 2.11 & 2.07 & 2.06 \\
\hline F-stat & 0.86 & 0.90 & 0.57 & 0.71 & 0.84 \\
\hline \multicolumn{6}{|c|}{ Panel C: Error correction term (t-values in parentheses) } \\
\hline \multirow[t]{2}{*}{ ECT } & -0.16 & -0.04 & -0.08 & -0.34 & $-0.12^{*}$ \\
\hline & $(-0.87)$ & $(-0.22)$ & $(-0.31)$ & $(-0.78)$ & $(-1.65)$ \\
\hline
\end{tabular}

Table 9. LGDP Regression on Public Issue.

*denotes $p<0.05,{ }^{* *}$ indicates $p<0.01$

The coefficients of the public issue (LPIS) in all models presented in Table 8 are positive and significant at the $5 \%$ level. This shows that primary market development has a significant and positive impact on economic growth in the long-run. Remittance and investment also have a positive impact on economic growth. The coefficients of error corrections presented in panel $\mathrm{C}$ are also negative and statistically significant showing that the deviation in long-run equilibrium is corrected by independent variables in the short-run.

Three out of five coefficients of GDP presented in panel $A$ of Table 8 are significant. However, the adjusted R2 of each model is negative, and error correction terms and model's F-statistic are also not significant. Therefore, this does not provide support in favor of economic growth causing the capital market development in the long-run. Similar is the case for short-run causality because only three out of five short-run coefficients of LPIS and none of the coefficients of LGDP presented in Table 9 are significant. Similarly, none of the coefficients of error terms are significant at 5\% meaning that economic growth cannot lead primary market development.

Table 10 shows that in the short-run, neither primary market development influences the economic growth nor economic growth influences the primary market development because none of the coefficients of GDP and LPIS is statistically significant. This shows that there is no short-run causal relationship between primary market development and economic growth in Nepal. 


\section{Conclusion}

The causality between financial development and economic growth has attracted many researchers and has become a matter of debate. Bank-based financial development is more cited in literature as compared to market-based financial development. Studies that consider the marketbased financial development also focused on the secondary market only. This study examined the causal relationship between economic growth and capital market, covering both primary and secondary market development. Using 26 annual time series data from 1994 to 2019, the two-way impact of growth to finance and finance to growth has been analyzed employing Johansen cointegration and the vector error correction model.

The findings from this study suggest that both primary market development and secondary market development support the economic development of Nepal. This indicates that the development of the primary market offers fundraising services to business organizations to invest in fixed assets. These services significantly help the output growth of the country. On the other hand, the development of the secondary market offers competitive price discovery and liquidity in terms of the transfer of funds from one sector to another. This function helps the economic growth through efficient allocation of funds in the area that it is needed most. Similarly, the findings from this study also confirm that, in the short-run, the development of the stock market (both primary and secondary) contributes positively to economic growth. However, economic growth does not support the development of the capital market in the long-run and short-run. The findings from this study support the findings of Durusu-Ciftci et al., (2016), Palamalai and Prakaham (2015, Bayar et al., (2014), and Nyasha and Odhiambo (2015) that capital market development leads to economic gorwth. However, this study contradicts Andriansyah and Messinis (2014) who found no effect of the primary market on economic development, Carp (2012) who found no causal relationship between capital market and economic growth in Central and Eastern Europe, and Pan and Mishra (2017) who found no clear evidence of the financial market causing growth in China. In summary, this study found unidirectional causality running from capital market development to the economic growth in

\begin{tabular}{|c|c|c|c|c|c|c|c|c|c|c|}
\hline & Mo & el 7 & Mo & el 8 & Mo & el 9 & Mod & 110 & Mos & el 11 \\
\hline & LGD & LPIS & LGD & LPIS & LGD & LPIS & LGDP & LPIS & LGDP & LPIS \\
\hline & P & & $\mathrm{P}$ & & $\mathrm{P}$ & & & & & \\
\hline GDP & & 0.68 & & 2.38 & & 0.70 & & 1.05 & & 2.91 \\
\hline & & $(.71)$ & & $(.50)$ & & $(.87)$ & & $(.79)$ & & $(.23)$ \\
\hline & 2.79 & & 17.62 & & 14.73 & & 27.43 & & 0.23 & \\
\hline LPIS & $(.250)$ & & $(.000)$ & & $(.002)$ & & $(.000)$ & & (.89) & \\
\hline Panel 2 & Residua & diagno & & & & & & & & \\
\hline Test & $x^{2}$ & $\mathrm{p}$ & $x^{2}$ & $\mathrm{p}$ & $\chi^{2}$ & $\mathrm{p}$ & $\chi^{2}$ & $\mathrm{p}$ & $\chi^{2}$ & $\mathrm{p}$ \\
\hline Norm & 0.24 & 0.88 & 0.70 & 0.70 & 0.41 & 0.81 & 0.02 & 0.99 & 0.90 & 0.63 \\
\hline Auto. & 6.14 & 0.11 & 2.18 & 0.53 & 6.96 & 0.07 & 6.06 & 0.13 & 0.23 & 0.89 \\
\hline Hetero & & & & & 6.22 & 0.10 & 0.35 & 0.94 & 0.20 & 0.90 \\
\hline . & 1.41 & 0.70 & 4.27 & 0.23 & & & & & & \\
\hline
\end{tabular}

Table 10. Short-Run Impact of Public Issue on Per Capita GDP. 
Nepal in the long-run and short-run. The findings support the supply-leading hypothesis.

\section{Implications}

Findings from this study suggest that increasing the size of the capital market to develop higher economic growth. The Nepal Stock Exchange can contribute to economic growth by increasing access to the people areas all over the country. Making a fully automated system may help to increase access to these people and people outside of the country. Similarly, increasing awareness about security transactions among people in rural areas may be another way of increasing the size of security turnover. Similarly, the policy of regulators that ensure fairness in trade and information can also help the development of the capital market. The reduction of barriers to the public issues of securities by the corporations may be helpful to the development of the primary market to spur economic growth. Further researchers can use new capital investment in the economy as an indicator of primary market development and the total value of securities traded as an indicator of secondary market to verify whether or not the result is consistent with the current study. Similarly, further research can extend this study by examining the role of capital market development on other areas of the economy such as the total factor productivity (TFP) growth.

\section{References}

Aghion, P., Hemous, D., \& Kharroubi, E. (2014). Cyclical fiscal policy, credit constraints, and industry growth. Journal of Monetary Economics, 62, 41-58.

Andriansyah, A., \& Messinis, G. (2014). Equity markets and economic development: Does the primary market matter? Economic Record, 90(S1), 127-141.

Arcand, J. L., Berkes, E., \& Panizza, U. (2015). Too much finance? Journal of Economic Growth, 20(2), 105-148.

Arestis, P., Demetriades, P. O., \& Luintel, K. B. (2001). Financial development and economic growth: The role of stock markets. Journal of Money, Credit and Banking, 33(1), 16-41.
Azam, M., Haseeb, M., Samsi, A. B., \& Raji, J. O. (2016). Stock market development and economic growth: Evidence from Asia-4 countries. International Journal of Economics and Financial Issues, 6(3), 1200-1208.

Bayar, Y., Kaya, A., \& Yildirim, M. (2014). Effects of stock market development on economic growth: Evidence from Turkey. International Journal of Financial Research, 5(1), 93-100.

Carp, L. (2012). Can stock market development boost economic growth? Empirical evidence from emerging markets in Central and Eastern Europe. Procedia Economics and Finance, 3(12), 438444.

Cecchetti, S. G., \& Kharroubi, E., (2015). Why does financial sector growth crowd out real economic growth? (Working paper No. 490). BIS.

Durusu-Ciftci, D., Ispir, M. S., \& Yetkiner, H. (2017). Financial development and economic growth: Some theory and more evidence. Journal of Policy Modeling, 39(2), 290-306.

Engle, R. F. \& Granger, C. W. J. (1987). Cointegration and error correction: Representation, estimation, and testing. Econometrica 55, 251-276.

Estrada, G. B., Park, D., \& Ramayandi, A. (2010). Financial development and economic growth in developing Asia (ADB Working paper, 233). ADB.

Ibrahim, M., \& Alagidede, P. (2017). Financial development, growth volatility and information asymmetry in Sub-Saharan Africa: Does law matter? South African Journal of Economics, 85(4), 570-588.

Johansen, S. (1991). Estimation and hypothesis testing of cointegration vectors in Gaussian Vector Autoregressive Models. Econometrica, $59,1551-80$.

Levine, R. \& Zervos, S. (1998). American economic association stock markets, banks and economic growth sources. The American Economic Review, 88(3), 537-558

Madura, J. (2015). Financial markets and institutions (11th ed.). Cengage Learning.

Mishkin F. S. Eakins, S. (2018). Financial markets and institutions. Pearson Education. 
Nazir, M. S., Nawaz, M. M., \& Gilani, U. J. (2010). Relationship between economic growth and stock market development. African Journal of Business Management, 4(16), 3473-3479.

Nepal Rastra Bank. (2018). Financial stability report. Kathmandu: NRB. Retrieved from https://www.nrb.org.np/contents/uploads/2019/1 2/Financial Stability Report-

Issue No. 10 July 2018-new.pdf

Nguyen, Q. H. (2019). Growth model with financial deepening and productivity heterogeneity. The Japanese Economic Review, $70(1), 123-140$.

Nyasha, S., \& Odhiambo, N. M. (2015). Banks, stock market development and economic growth in South Africa: A multivariate causal linkage. Applied Economics Letters, 22(18), 1480-1485.

Odhiambo, N. M. (2009a). Finance-growthpoverty nexus in South Africa: A dynamic causality linkage. Journal of Socio-Economics, 38(2), 320-325.

Omri, A., Daly, S., Rault, C., \& Chaibi, A. (2015). Financial development, environmental quality, trade and economic growth: What causes what in MENA countries? Energy Economics, 48, 242252.
Palamalai, S., \& Prakasam, K. (2015). Stock market development and economic growth in India: An empirical analysis. International Journal of Finance \& Banking Studies, 5(3), 361-375.

Pan, L., \& Mishra, V. (2018). Stock market development and economic growth: Empirical evidence from China. Economic Modelling, 68(2018), 661-673.

Pradhan, R. P., Arvin, M. B., Hall, J. H., \& Bahmani, S. (2014). Causal nexus between economic growth, banking sector development, stock market development, and other macroeconomic variables: The case of ASEAN countries. Review of Financial Economics, 23(4), 155-173.

Schumpeter, J. A. (1911). The theory of economic development. [English translation]. Harvard University Press.

Sharif, A., \& Afshan, S. (2016). Impact of stock market on economic growth of Pakistan. International Journal of Economics and Empirical Research, 4(10), 562-570.

Wendel, C. B., \& Harvey, M. (2006). SME credit scoring: Key initiatives, opportunities, and issues (No. 38955, pp. 1-6). The World Bank. 